\title{
Milk production and somatic cell counts: A cow-level analysis
}

\author{
K. J. Hand, ${ }^{\star 1}$ A. Godkin,, and D. F. Kelton¥ \\ *Strategic Solutions Group, Puslinch, ON, Canada, NOB 2J0 \\ †Ontario Ministry of Agriculture, Food and Rural Affairs, Elora, ON, Canada, NOB 1S0 \\ ¥Population Medicine, University of Guelph, Guelph, ON, Canada, N1G 2W1
}

\begin{abstract}
The objectives of this study were to quantify the relationship between 24-h milk loss and lactation milk loss due to mastitis at the cow level. For the year 2009, individual cow test-day production records from 2,835 Ontario dairy herds were examined. Each record consisted of 24-h milk and component yields, stage of lactation (days in milk, DIM), somatic cell count $\left(\mathrm{SCC}, \times 10^{3}\right.$ cells $/ \mathrm{mL}$ ) and parity. The modeling was completed in 2 stages. In stage 1, for each animal in the study, the estimated slope from a linear regression of 24-h milk yield $(\mathrm{kg})$, adjusted for DIM, the quadratic effect of DIM, and the 24 -h fat yield $(\mathrm{kg})$ on $\ln (\mathrm{SCC})$ was determined. In stage 2 , the estimated slope were modeled using a mixed model with a random component due to herd. The fixed effects included season (warm: May to September, cool: October to April), milk quartile class [MQ, determined by the rank of the 24-h average milk yield $(\mathrm{kg})$ over a lactation within the herd] and parity. The estimated slopes from the mixed model analysis were used to estimate $24-\mathrm{h}$ milk loss $(\mathrm{kg})$ by comparing to a referent healthy animal with an SCC value of 100 $\left(\times 10^{3}\right.$ cells $\left./ \mathrm{mL}\right)$ or less. Lactation milk loss $(\mathrm{kg})$ was then estimated by using estimated 24-h milk loss within lactation by means of a test-day interval method. Lactation average milk loss $(\mathrm{kg})$ and SCC were also estimated. Lastly, lactation milk loss $(\mathrm{kg})$ was modeled on the log scale using a mixed model, which included the random effect of herd and fixed effects, parity, and the linear and quadratic effect of the number of 24-h test days within a lactation where SCC exceeded $100\left(\times 10^{3}\right.$ cells/mL; S100). The effect of SCC was significant with respect to $24-\mathrm{h}$ milk loss $(\mathrm{kg})$, increasing across parity and MQ. In general, first-parity animals in the first MQ (lower milk yield animals) were estimated to have $45 \%$ less milk loss than later parity animals. Milk losses were estimated to be $33 \%$ less for animals in first parity and MQ 2 through 4 than later parity animals in comparable MQ. Therefore, the relative level of milk
\end{abstract}

Received September 12, 2011.

Accepted November 10, 2011.

${ }^{1}$ Corresponding author: karen.hand@strategicsolns.ca production was found to be a significant risk factor for milk loss due to mastitis. For animals with 24-h SCC, values of $200\left(\times 10^{3}\right.$ cells $\left./ \mathrm{mL}\right), 24$-h milk loss ranged from 0.35 to $1.09 \mathrm{~kg}$; with 24-h SCC values of 2,000 $\left(\times 10^{3}\right.$ cells $\left./ \mathrm{mL}\right)$, milk loss ranged from 1.49 to 4.70 $\mathrm{kg}$. Lactation milk loss $(\mathrm{kg})$ increased significantly as lactation average SCC increased, ranging from 165 to $919 \mathrm{~kg}$. The linear and quadratic effect of S100 was a significant risk factor for lactation milk loss $(\mathrm{kg})$, where greatest losses occurred in lactations with 5 or more 24-h test days where SCC exceeded $100\left(\times 10^{3}\right.$ cells/ $\mathrm{mL}$ ).

Key words: milk production, mastitis, somatic cell count

\section{INTRODUCTION}

It is a truism: the economic loss due to mastitis is considerable and worldwide. Economic losses are a consequence of control costs and decreased production, the most significant loss resulting from diminished milk production (DeGraves and Fetrow, 1993; Seegers et al., 2003). Typically, the severity of mastitis is measured in terms of milk SCC, where higher levels indicate increased inflammation. To quantify the economic impact of mastitis on dairy herds, it is therefore crucial to quantify the relationship between milk SCC and yield.

Numerous studies have been published attempting to quantify the relationship between SCC concentration and milk production. Pioneering research by Raubertas and Shook (1982) estimated the amount of milk loss in lactation with every unit increase in lactation average $\ln (\mathrm{SCC})$. Publications then progressed to include a wide variety of SCC criteria and periods of milk production in which to quantify the SCC and milk yield relationship (Lescourret and Coulon, 1994; Barkema et al., 1999). Some studies concentrate on estimating testday or 24-h milk loss (Jones et al., 1984; Bartlett et al., 1990; Hortet, et al., 1999; Dürr et al., 2008; Halasa et al., 2009). Miller et al. (2004) examined both lactation and test-day milk loss due to SCC. Other studies examined the SCC and milk yield relationship for a definitive type of dairy herd (Tyler et al., 1989). Reviews of the literature have been done as well as meta-analyses that 
collate the literature regarding milk loss due to SCC at both the test-day and lactation levels (Seegers et al., 2003; Halasa et al., 2007). However, a lack of research exists where the relationship between milk production loss and SCC at the cow level is quantified. Only 2 papers (Barkema et al., 1999; Hortet et al., 1999) recognize the correlations due to repeated observations on animals and account for the correlation in the error.

Many studies, to simplify the modeling process (or as an artifact of the study design) include only 1 observation per animal (Jones et al., 1984; Dürr et al., 2008; Halasa et al., 2009). Furthermore, no studies have examined milk production as a risk factor for production loss. As suggested by Seegers et al. (2003), multiparous animals that experience mastitis tend to be higher producing and, therefore, ignoring milk production as a risk factor can lead to underestimation of milk loss. Green et al. (2006) find evidence of a SCC dilution effect in high-producing cows with no IMI, which could result in the overestimation of milk loss with increasing SCC.

The objectives of this study were to determine $24-\mathrm{h}$ milk loss due to mastitis by quantifying the relationship between 24-h milk yield and SCC at the cow level, to examine milk production as a risk factor, and finally, to estimate lactation milk loss due to mastitis.

\section{MATERIALS AND METHODS}

\section{Data}

For the year 2009, test-day records from Ontario Holstein cows were collected for a total of 869,414 records from 115,617 animals in 2,835 herds. The average herd size was 73 animals. Each test-day record included $24-\mathrm{h}$ milk and component yields, stage of lactation ranging from 15 to 400 DIM, parity $(\mathbf{P A R})$, and SCC $\left(\times 10^{3}\right.$ cells $/ \mathrm{mL}$ ), determined by using the Series 5000 Fossomatic (Foss A/S, Hillerød, Denmark), at the CanWest DHI Analysis Centre located in Guelph, Ontario, Canada.

\section{Data Analysis}

For each observation, the following variables were recorded: SCC $\left(\times 10^{3}\right.$ cells $\left./ \mathrm{mL}\right), 24$-h milk yield $(\mathrm{kg})$, 24-h fat yield (kg), DIM, PAR (for parities 1, 2, and 3 to 5), season (warm: May to September, cool: October to April), and milk quartile class (MQ), determined by ranking the average test-day milk yield ( $\mathrm{kg}$; average of all test-day records in a given lactation) for each animal according to milk production quartiles within the herd. Only test-day records for parities 1 through 5 and DIM between 15 and 400 were included in the analyses. All animals in the study were required to have at least 6 test-day records and to have reached at least 150 DIM. The maximum SCC value recorded was 25 million.

The modeling was completed in 2 stages. In stage 1, for each animal in the study, the estimated slope from a linear regression of $24-\mathrm{h}$ milk yield $(\mathrm{kg})$, adjusted for DIM, the quadratic effect of DIM, and the 24-h fat yield $(\mathrm{kg})$ on $\log (\mathrm{SCC} / 100)$, was determined. The regression analysis was performed using PROC GLM in SAS 9.2 (SAS Institute Inc., Cary, NC). In stage 2, the estimated slope were modeled using PROC MIXED in SAS 9.2 (SAS Institute Inc.). Fixed effects in the model included season, MQ and PAR. The random effect for herd was also included in the model.

For the purpose of this study, a healthy referent animal was defined to be any cow with a 24-h SCC of less than or equal to $100\left(\times 10^{3}\right.$ cells $\left./ \mathrm{mL}\right)$ and a mastitic cow to be any cow with a 24-h SCC greater than 100 $\left(\times 10^{3}\right.$ cells $\left./ \mathrm{mL} ; \mathbf{S 1 0 0}\right)$. The results of the mixed model analysis provided the estimated change in 24-h milk yield $(\mathrm{kg})$ due to $\operatorname{SCC}\left(\mathrm{b}_{1}\right)$. The 24-h milk loss $(\mathrm{kg})$ for a given PAR and MQ at fixed values of SCC were estimated by $b_{1} \times \log (100 / S C C)$.

The estimated slopes from the mixed model analysis were used to estimate $24-\mathrm{h}$ milk loss $(\mathrm{kg})$ by comparing to a referent animal with an SCC value of $100\left(\times 10^{3}\right.$ cells $/ \mathrm{mL}$ ). Milk loss equations estimate the 24 -h milk loss (kg) per unit change in SCC compared with a healthy animal with an SCC value of $100\left(\times 10^{3}\right.$ cells/ $\mathrm{mL}$ ) or less.

Using estimates of 24-h milk loss $(\mathrm{kg})$ on each test day, lactation milk loss $(\mathrm{kg})$ was then calculated, using a test-interval method as outlined by Sargent et al. (1968). Lactation milk loss was calculated only for animals with a complete lactation record. A complete lactation was defined to be lactation where at least 6 test-day records were observed starting before 60 DIM and ending after 150 DIM. Therefore, minimum lactation length was found to be $150 \mathrm{~d}$, with a maximum of $400 \mathrm{~d}$ and an average lactation length of $279 \mathrm{~d}$. The number of test days within the lactation where SCC exceeded $100\left(\times 10^{3}\right.$ cells $\left./ \mathrm{mL}\right)$ was also calculated. The data set contained a total of 72,113 completed lactations. For the sake of comparison with previous studies, total lactation SCC was calculated using a test-interval method with the observed test-day SCC counts; this was then divided by lactation length to obtain the average lactation SCC.

For all completed lactations, the number of test days with S100 were summarized. Using PROC MIXED in SAS 9.2 (SAS Institute Inc.), the log of lactation loss $(\mathrm{kg})$ was modeled. The model included the linear and 
Table 1. Equations for estimating 24 -h milk loss $(\mathrm{kg})$ per unit change in SCC $\left(\times 10^{3}\right.$ cells $\left./ \mathrm{mL}\right)$ by parity $(\mathrm{PAR})$ and within-herd milk production quartile (MQ) and PAR

\begin{tabular}{lcccc}
\hline & \multicolumn{4}{c}{ MQ } \\
\cline { 2 - 5 } PAR & 1 & 2 & 3 & 4 \\
\hline 1 & $0.50 \ln ($ SCC $)-2.30$ & $0.71 \ln ($ SCC $)-3.28$ & $0.81 \ln ($ SCC $)-3.71$ & $1.16 \ln ($ SCC $)-5.34$ \\
2 & $0.89 \ln ($ SCC $)-4.08$ & $1.10 \ln ($ SCC $)-5.06$ & $1.19 \ln ($ SCC $)-5.49$ & $1.55 \ln ($ SCC $)-7.12$ \\
3 & $0.91 \ln ($ SCC $)-4.18$ & $1.12 \ln ($ SCC $)-5.16$ & $1.21 \ln ($ SCC $)-5.59$ & $1.57 \ln ($ SCC $)-7.22$ \\
\hline
\end{tabular}

quadratic fixed effect of the number of test days with S100 and the linear fixed effect of PAR. The random effect of herd was also included.

\section{RESULTS AND DISCUSSION}

The mixed model resulted in significant effects of $\mathrm{MQ}$ and $\mathrm{P}(P<0.0001)$. The fixed effect of season was not significant $(P=0.49)$. Milk loss equations for estimating 24 -h milk loss $(\mathrm{kg})$ per unit change in SCC can be found in Table 1. For example, an animal in MQ 3 and PAR 2 with an SCC value of $400\left(\times 10^{3}\right.$ cells $\left./ \mathrm{mL}\right)$ has an estimated 24 -h milk loss of $1.65 \mathrm{~kg}$.

In Table 2, estimated 24-h milk loss ( $\mathrm{kg}$ ) for various SCC values is given. Milk loss $(\mathrm{kg})$ increased with increasing PAR and across MQ. First-PAR animals in MQ 1 demonstrated $45 \%$ less milk loss than those in MQ 1 in older PAR, which agrees with the results of Jones et al. (1984), who, in general, found that losses in first lactation were only $50 \%$ of those in later lactations. However, in MQ 2, MQ 3, and MQ 4, the percentage loss for first-PAR animals was only 36,33 , and $26 \%$ less, respectively, than that for animals in later PAR. As suggested by Seegers et al. (2003), milk production (measured as MQ) is a significant risk factor, with higher-producing animals (MQ 4) exhibiting greater milk loss. Milk loss was not adjusted for the dilution effect suggested by Green et al. (2006); to date, the dilution effect has not been quantified.

Table 3 contains estimated milk loss $(\mathrm{kg})$ for differing values of SCC and compares these to estimates previously published. The referent SCC value was adjusted to be $100\left(\times 10^{3}\right.$ cells $\left./ \mathrm{mL}\right)$ wherever possible. A large variation exists in the results shown, with the estimates from the current study tending toward the upper end or exceeding the other published figures. Halasa et al. (2007), in a review of the literature, also found variations when comparing results and suggested that it may be due to differences in geographic areas. Seegers et al. (2003) observed that studies differed in terms of study time frames and differences in modeling approaches. However, none of the previous published studies attempt to summarize the relationship between milk yield and SCC at the cow level.

For all completed lactations in the data set, total lactation milk loss $(\mathrm{kg})$ was calculated and classified by the lactation average SCC. The results are presented in Table 4. As expected, lactation milk loss ( $\mathrm{kg}$ ) increases as lactation average SCC increases. Lactation milk loss $(\mathrm{kg})$ is approximately $50 \%$ more in older animals compared with first-PAR animals. The estimates of lactation milk loss previously published by Raubertas and Shook (1982) were lower. This difference could be accounted for by the difference in modeling approaches

Table 2. Estimated 24-h milk loss (expressed in kilograms and percent) for specific values of SCC $\left(\times 10^{3}\right.$ cells $\left./ \mathrm{mL}\right)$ by parity $(\mathrm{PAR})$ and withinherd milk production quartile (MQ)

\begin{tabular}{|c|c|c|c|c|c|c|c|c|c|c|c|c|c|}
\hline PAR & MQ & \multicolumn{6}{|c|}{$\mathrm{SCC}(\mathrm{kg})$} & \multicolumn{6}{|c|}{$\operatorname{SCC}\left(\%^{1}\right)$} \\
\hline \multirow[t]{3}{*}{1} & 1 & 0.35 & 0.80 & 1.04 & 1.15 & 1.35 & 1.49 & 1.44 & 3.34 & 4.32 & 4.78 & 5.63 & 6.23 \\
\hline & 3 & 0.56 & 1.30 & 1.68 & 1.86 & 2.18 & 2.41 & 1.72 & 3.99 & 5.16 & 5.71 & 6.71 & 7.43 \\
\hline & 4 & 0.80 & 1.87 & 2.41 & 2.67 & 3.14 & 3.48 & 2.15 & 4.99 & 6.45 & 7.15 & 8.40 & 9.30 \\
\hline 2 & 1 & 0.61 & 1.42 & 1.84 & 2.04 & 2.40 & 2.65 & 2.46 & 5.72 & 7.39 & 8.18 & 9.62 & 10.65 \\
\hline \multirow[t]{4}{*}{3} & 1 & 0.63 & 1.46 & 1.89 & 2.09 & 2.46 & 2.72 & 2.43 & 5.64 & 7.28 & 8.06 & 9.48 & 10.49 \\
\hline & 2 & 0.78 & 1.80 & 2.33 & 2.58 & 3.03 & 3.35 & 2.55 & 5.91 & 7.64 & 8.45 & 9.94 & 11.00 \\
\hline & 3 & 0.84 & 1.95 & 2.52 & 2.80 & 3.29 & 3.64 & 2.37 & 5.50 & 7.11 & 7.87 & 9.26 & 10.24 \\
\hline & 4 & 1.09 & 2.52 & 3.26 & 3.61 & 4.25 & 4.70 & 2.68 & 6.22 & 8.04 & 8.90 & 10.46 & 11.58 \\
\hline
\end{tabular}

${ }^{1}$ Percent of average 24-h milk yield of animals with comparable PAR and MQ where SCC $\leq 100\left(\times 10^{3}\right.$ cells $\left./ \mathrm{mL}\right)$. 
Table 3. Estimates of 24 -h milk loss $(\mathrm{kg})$ for specific SCC $\left(\times 10^{3}\right.$ cells $\left./ \mathrm{mL}\right)$ values by parity (PAR) and within-herd milk production quartile (MQ) compared with previously published studies

\begin{tabular}{|c|c|c|c|c|c|c|c|c|}
\hline \multirow[b]{2}{*}{ PAR } & \multirow[b]{2}{*}{ MQ } & \multicolumn{2}{|c|}{$\mathrm{SCC}$} & \multicolumn{2}{|c|}{ Hortet et al. $(1999)^{1}$} & \multicolumn{2}{|c|}{ Dürr et al. $(2008)^{1}$} & \multirow{2}{*}{$\frac{\text { Halasa et al. }(2009)^{2}}{200}$} \\
\hline & & 200 & 600 & 200 & 600 & 200 & 600 & \\
\hline \multirow{2}{*}{1} & 3 & 0.56 & 1.44 & & & & & \\
\hline & 4 & 0.80 & 2.08 & & & & & \\
\hline \multirow[t]{2}{*}{2} & 1 & 0.61 & 1.59 & 0.31 & 0.81 & 0.53 to 1.25 & 1.36 to 3.23 & 0.44 to 0.56 \\
\hline & 4 & 1.07 & 2.77 & & & & & \\
\hline \multirow[t]{4}{*}{$\geq 3$} & 1 & 0.63 & 1.63 & 0.3 & 0.77 & & & \\
\hline & 2 & 0.78 & 2.01 & & & & & \\
\hline & 3 & 0.84 & 2.18 & & & & & \\
\hline & 4 & 1.09 & 2.81 & & & & & \\
\hline
\end{tabular}

${ }^{1}$ Referent SCC of $100\left(\times 10^{3}\right.$ cells $\left./ \mathrm{mL}\right)$.

${ }^{2}$ Referent SCC of $50\left(\times 10^{3}\right.$ cells $\left./ \mathrm{mL}\right)$

as well as the genotypic and phenotypic changes in the Holstein breed over the 30 intervening years.

The mixed model examining the linear and quadratic effect of S100, accounting for PAR, on lactation loss $(\mathrm{kg})$ was significant $(P<0.0001)$. In Figure 1 , using the solution for the fixed effects, the volume of lactation production loss $(\mathrm{kg})$ is plotted against S100 by lactation. These results suggest that for cows in PAR 2 and greater, the increase in milk loss with elevated $\mathrm{SCC}$ is not linearly related to the number of test days with S100. In fact, as the number of test days with S100 increases, the increase in milk loss follows a quadratic relationship. Although this has not been described in the previous studies cited, this observation is consistent with our understanding of the physiological effect of chronic subclinical and clinical infection on the milkproducing parenchyma of the mammary gland.

\section{CONCLUSIONS}

A measurable loss in milk production due to mastitis continues to exist, as measured by SCC. Milk loss can be quantified for a 24 -h period or across lactation. These milk loss estimates are larger, particularly for first-PAR animals, than have been previously reported in the literature. Further, high-producing animals demonstrated greater milk loss than did lower-producing animals when ranked on the basis of milk yield within herd, demonstrating that cow-level milk production is a significant risk factor in milk loss. The number of test

Table 4. Estimated average lactation milk loss $(\mathrm{kg})$ classified by lactation average $\mathrm{SCC}\left(\times 10^{3} \mathrm{cells} / \mathrm{mL}\right)$ by parity (PAR)

\begin{tabular}{|c|c|c|c|c|c|c|c|}
\hline \multicolumn{2}{|c|}{ Average SCC } & \multicolumn{6}{|c|}{ PAR } \\
\hline $\mathrm{LB}^{1}$ & $\mathrm{UB}^{2}$ & 1 & 2 & 3 & $1^{3}$ & $2^{3}$ & $3^{3}$ \\
\hline 100 & 200 & 165 & 348 & 381 & 54 & 116 & 110 \\
\hline 200 & 300 & 196 & 372 & 423 & 123 & 262 & 248 \\
\hline 300 & 400 & 253 & 444 & 503 & 168 & 358 & 339 \\
\hline 400 & 500 & 314 & 526 & 561 & 202 & 430 & 408 \\
\hline 500 & 600 & 327 & 555 & 614 & 228 & 488 & 462 \\
\hline 600 & 700 & 366 & 621 & 663 & 251 & 535 & 507 \\
\hline 700 & 800 & 393 & 671 & 718 & 270 & 576 & 546 \\
\hline 800 & 900 & 415 & 702 & 755 & 287 & 612 & 580 \\
\hline 900 & 1,000 & 445 & 722 & 800 & 302 & 644 & 610 \\
\hline 1,000 & 1,100 & 438 & 722 & 823 & 315 & 672 & 637 \\
\hline 1,100 & 1,200 & 479 & 810 & 859 & 327 & 699 & 662 \\
\hline 1,200 & 1,300 & 487 & 816 & 872 & 338 & 722 & 684 \\
\hline 1,300 & 1,400 & 491 & 851 & 880 & 349 & 744 & 705 \\
\hline 1,400 & 1,500 & 501 & 844 & 919 & 358 & 765 & 725 \\
\hline
\end{tabular}

${ }^{1}$ Lower bound of lactation average SCC $\left(\times 10^{3}\right.$ cells $\left./ \mathrm{mL}\right)$.

${ }^{2}$ Upper bound of lactation average SCC $\left(\times 10^{3}\right.$ cells $\left./ \mathrm{mL}\right)$.

${ }^{3}$ Estimated average lactation milk loss $(\mathrm{kg})$ at midpoint of class following Raubertas and Shook (1982). 


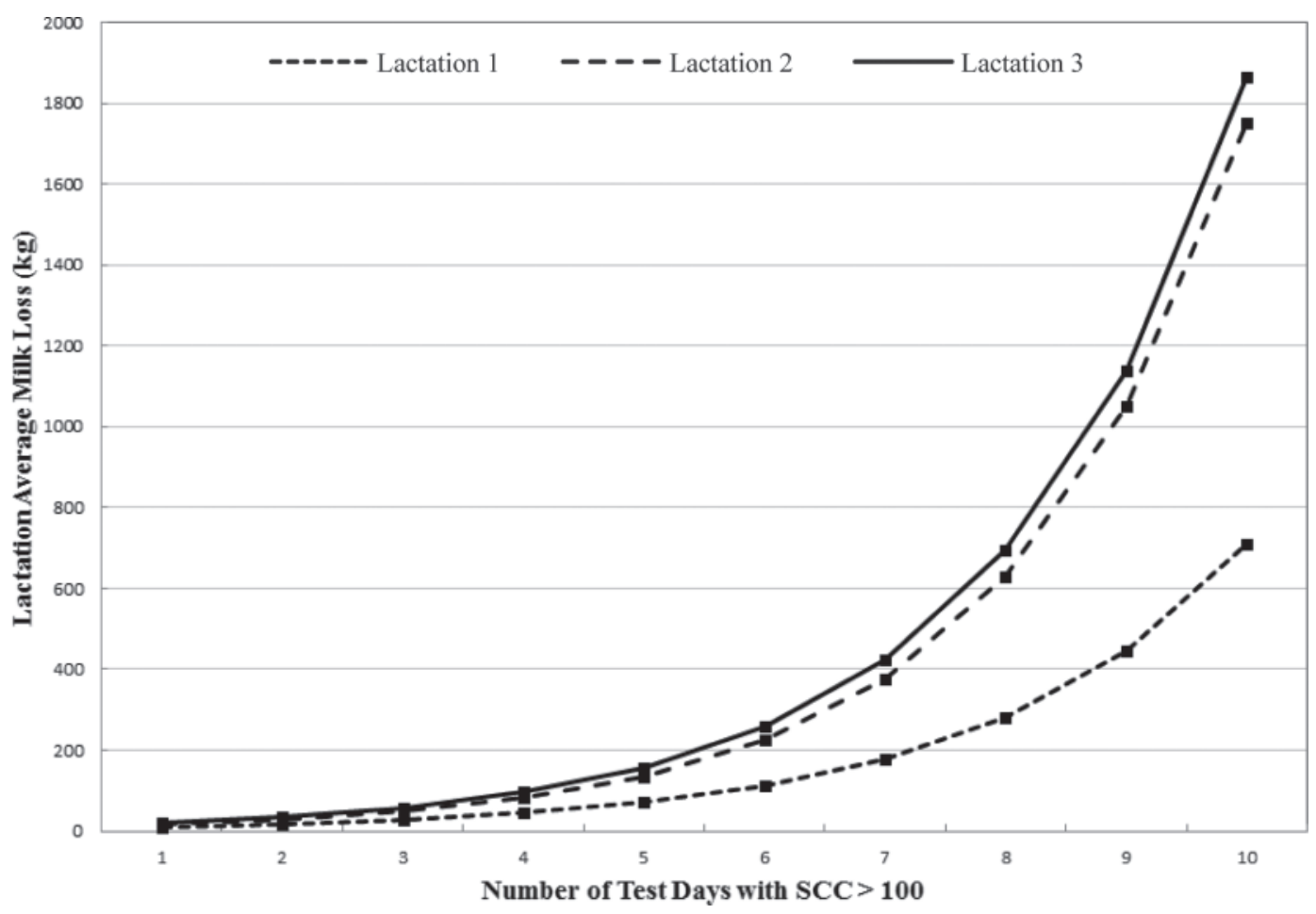

Figure 1. Estimated lactation milk loss $(\mathrm{kg})$ plotted against the number of lactation test days where $\mathrm{SCC}$ exceeded $100\left(\times 10^{3}\right.$ cells $/ \mathrm{mL}$; S100).

days with elevated SCC within lactation was found to be an additional and significant risk factor for increased lactation milk loss, with the greatest production loss occurring when the lactation had 5 or more test days with S100.

\section{ACKNOWLEDGMENTS}

Financial support for this study was provided by CanWest DHI (Guelph, ON, Canada). The data for this study were provided by CanWest DHI (Guelph, ON, Canada) and the Dairy Farmers of Ontario (Mississauga, ON, Canada). The authors thank Ian Rumbles and Richard Cantin (CanWest DHI) for all of their assistance and expertise in the production of this manuscript.

\section{REFERENCES}

Barkema, H. W., H. A. Deluyker, Y. H. Schukken, and T. J. G. M Lam. 1999. Quarter-milk somatic cell count at calving and at the first six milkings after calving. Prev. Vet. Med. 38:1-9.

Bartlett, P. C., G. Y. Miller, C. R. Anderson, and J. H. Kirk. 1990. Milk production and somatic cell count in Michigan dairy herds. J. Dairy Sci. 73:2794-2800.

DeGraves, F. J., and J. Fetrow. 1993. Economics of mastitis and mastitis control. Vet. Clin. North Am. Food Anim. Pract. 9:421-434.

Dürr, J. W., R. I. Cue, H. G. Monardes, J. Moro-Méndez, and K. M. Wade. 2008. Milk losses associated with somatic cell counts per breed, parity and stage of lactation in Canadian dairy cattle. Livest. Sci. 117:225-232.
Green, L. E., Y. H. Schukken, and M. J. Green. 2006. On distinguishing cause and consequence: Do high somatic cell counts lead to lower milk yield or does high milk yield lead to lower somatic cell count? Prev. Vet. Med. 76:74-89.

Halasa, T., K. Huijps, O. Østerås, and H. Hogeveen. 2007. Economic effects of bovine mastitis and mastitis management: A review. Vet. Q. 29:18-31.

Halasa, T., M. Nielen, A. P. W. De Roos, R. Van Hoorne, G. de Jong, T. J. G. M. Lam, T. van Werven, and H. Hogeveen. 2009. Production loss due to new subclinical mastitis in Dutch dairy cows estimated with a test-day model. J. Dairy Sci. 92:599-606.

Hortet, P., F. Beaudeau, H. Seegers, and C. Fourichon. 1999. Reduction in milk yield associated with somatic cell counts up to 600,000 cells/ml in French Holstein cows without clinical mastitis. Livest. Prod. Sci. 61:22-42.

Jones, G. M., R. E. Pearson, G. A. Clabaugh, and C. W. Heald. 1984. Relationship between somatic cell counts and milk production. J. Dairy Sci. 67:1823-1831.

Lescourret, F., and J. B. Coulon. 1994. Modeling the impact of mastitis on milk production by dairy cows. J. Dairy Sci. 77:2289-2301.

Miller, R. H., H. D. Norman, G. R. Wiggans, and J. R. Wright. 2004. Relationship of test-day somatic cell score with test-day and lactation milk yields. J. Dairy Sci. 87:2299-2306.

Raubertas, R. F., and G. E. Shook. 1982. Relationship between lactation measures of somatic cell concentration and milk yield. J. Dairy Sci. 65:419-425.

Sargent, F. D., V. H. Lytton, and O. G. Wall Jr. 1968. Test interval method of calculating Dairy Herd Improvement Association records. J. Dairy Sci. 51:170-179.

Seegers, H., C. Fourichon, and F. Beaudeau. 2003. Production effects related to mastitis and mastitis economics in dairy cattle herds. Vet. Res. 34:475-491.

Tyler, J. W., M. C. Thurmond, and L. Lasslo. 1989. Relationship between test-day measures of somatic cell count and milk production in California dairy cows. Can. J. Vet. Res. 53:182-187. 